\title{
VEDDA (VANNIYALETTO) AS FOLK LIFE: INTANGIBLE CULTURAL HERITAGE IN SRI LANKA
}

\author{
David Blundell
}

\author{
National Chengchi University, Taipei \\ Electronic Cultural Atlas Initiative (ECAI) \\ pacific@berkeley.edu
}

\begin{abstract}
This paper addresses potential folk life cultural heritage in Sri Lanka as a continuum in a country of magnificent UNESCO listed sites. If the Vedda (Vanniyaletto) of Sri Lanka are the heirs of an existence dating back to the Mesolithic of Southern Asia to the present, then this community represents a sphere of cultural expression that requires world attention in conserving a folk diversity that is rapidly disappearing. These Vanniyaletto, continue living in a land of significant ancient world heritage, are struggling for years to have a museum or community center dedicated to their existence. While some critics proclaim they don't exist as a people, I argue the Vedda are not a primitive or non-existent 'tribe'; they are an important heritage community in Sri Lanka laying a foundation, in part, for a plural nation (Blundell 2008). They are a people wrapped in the matrix of the Sinhala and Tamil communities from earliest times, yet since the 19th century relegated as a fringe people, curiosities at best, without acknowledgement as significant contributors in today's 'national program'.
\end{abstract}

\section{SRI LANKA AND ITS WORLD HERITAGE}

Sri Lanka has a 2500-year old written history. By the first millennium C.E. its Buddhist civilization and cultural heritage were being adopted throughout many parts of Southeast Asia. Heritage consciousness in Sri Lanka has been gaining momentum since the revival of interest in its ancient Buddhist civilization with the establishment of the Archaeological Survey under British colonial rule in the 19th century. In Sri Lanka, during the first half of the 20th century, the British led the quest to excavate ruins and cultural remains in the Sri Lanka jungle, giving impetus to the eventual establishment of national aims.

Since the mid-1980s, the government of Sri Lanka has been expanding its world heritage sites for cultural and natural significance. National aims were achieved with establishment of world-recognized sites documenting the legacy of the Anuradhapura civilization, with its ancient expanse of cities, temples, and monuments, forming the basis for the United Nations Educa- tional, Scientific, and Cultural Organization (UNESCO) 'Cultural Triangle'.

The Cultural Triangle was initiated when the Sri Lanka team of UNESCO, preparing the action plan for the campaign, noticed that there was an array of monuments or sites that needed international attention and assistance. The six Cultural Triangle sites were selected on the merits of their uniqueness in history.

As an initiator of hydraulic civilization in Sri Lanka, Anuradhapura flourished (500 B.C.E. to the 10 th century C.E.). Its Abhayagiri Monastery, by the 5 th century C.E. had 5000 Buddhist monks, emerging as one of the largest religious institutions in history. Also, Jetavana Monastery claimed the world's largest stupa at 404 feet in height.

After the collapse of Anuradhapura, a city developed further to the southeast on the northern plain, Polonnaruva (993 C.E. to 1235 C.E.) along with its great university Alahana Parivena in the 12 th century C.E.

Other unique sites were chosen including an early paradigm of sacred palatial water gardens at Sigiriya, the 5 th century paramount rock formation styled abode of the 'god-king' Kassapa I. The Golden Rock Temple Shrine of Dambulla with 20,000 square feet of painted murals in five cave shrines dating from the 7 th to 18 th centuries C.E. was selected as an important cultural treasure in need of preservation as well.

Kandy in the central highlands is especially unique as a royal pilgrimage site and the seat of the last ancient kingdom (14th to 19th centuries). It is a living treasure of ritual and worship with an annual pageant of the Tooth Relic Shrine (Dalada Maligava) dating back, in its ritual expressions, to the 5th century C.E. in Anuradhapura.

Two World Heritage sites not included in the Cultural Triangle are: (1) Singharaja Forest Reserve is a pristinely unique, lofty, cloud-shrouded eco-niche richly endowed with newly discovered and classified endemic species of wildlife. (2) Galle Fort at the southern end of the island. The colonial Portuguese built fortifications in the 
1580 s, reinforced extensively by Dutch building the walled town from the 17 th century C.E. Within the fort resides the local population.

The Cultural Triangle was initiated by the Sri Lanka Board of Governors of the Central Cultural Fund, which is composed of the Prime Minister as chairman together with six Cabinet Ministers and several other appointed officials managing campaign activities. Commissioned work from UNESCO, with a budget of US\$54 million, employed about 4500 personnel, including administrators, working with another 500 graduates in archaeology, art, architecture, and other related disciplines (Roland Silva pers. comm.).

The designated heritage sites are precious to the people of Sri Lanka and are often visited by local people as a way of reinforcing their cultural identity. Pilgrims following their ritual Buddhist practice en route to the shrines of the ancient cities make stops at the historic institutions, immersing themselves in the artifacts of past ages.

Yet, the 'intangible' indigenous aspects of the living cultures are currently not appreciated as much as are the monumental sites. Compared to the historic monuments, the more intangible living treasures in Sri Lanka, such as the folk traditions, have been neglected, or seen as a curiosity. I contend that tangible and intangible heritages of Sri Lanka require equal attention (Figure 1).

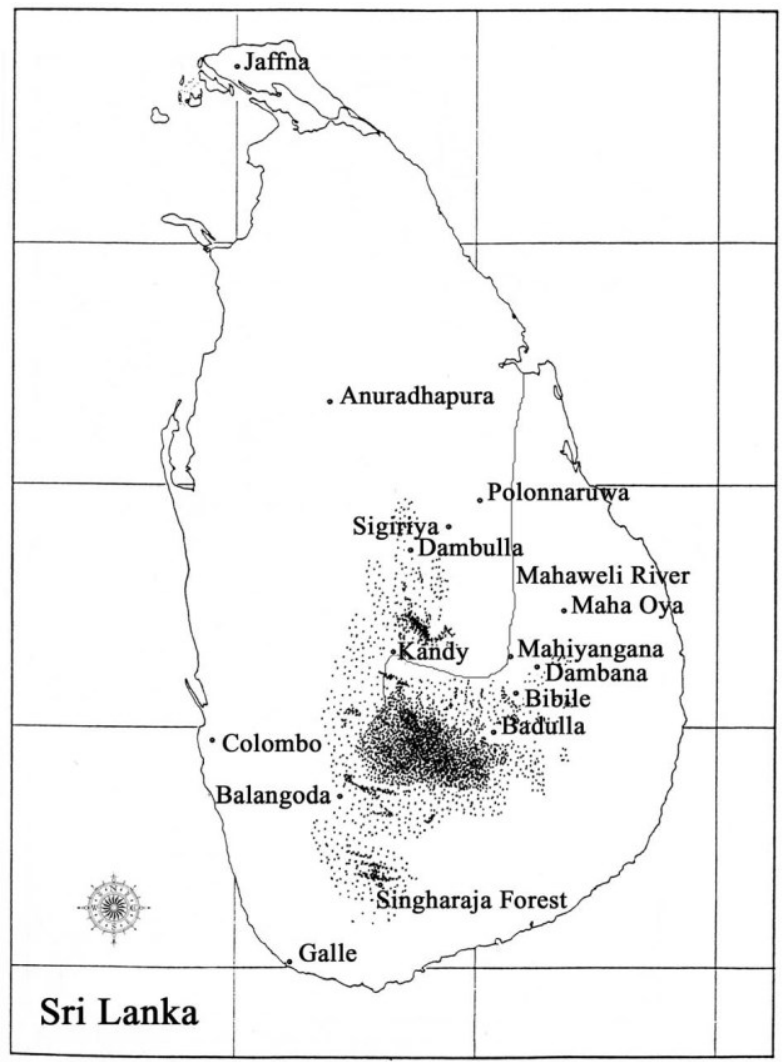

Figure 1. Map of Sri Lanka.

With tangible heritage monuments joining international rosters supported by agencies of the national govern- ment and UNESCO, the intangible living heritages that exist in Sri Lanka have been treated as 'out-station' curiosities: an embarrassment to better-educated urbanites. Innumerable prominent intangible elements of folk life continue away from the mainstream.

What is the worth and value of local performance such as southern Ruhunu mask dance for healing and drama (Blundell 2011)? Specific locations across the country have separate, yet related, traditions that include palm leaf weaving, pottery, metalwork, jewelry, batik, constructing boats, wood and stone carving, and other innumerable crafts. Understanding contemporary sources and uses of these life ways is vital to appreciating what is called the national heritage.

My research with the Vanniyaletto communities, first introduced in 1973, and subsequently from 1975-1976 and in 1981 at Dambana, Mahiyangana, again conducted at Dambana in 2002-2003 (Figure 2) (see Blundell 2004, 2007, In Press), has revealed the following observations.

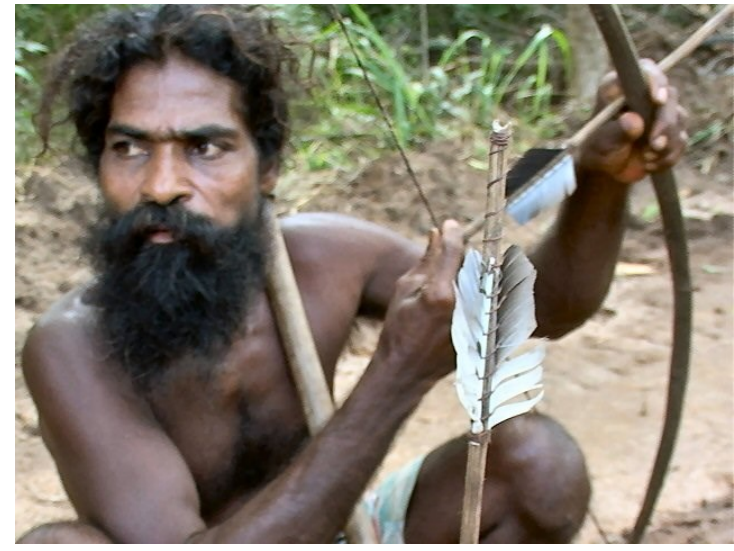

Figure 2. Sidubanda at Dambana, 2003 (photo by author).

The early communities of Sri Lanka, the Vedda, have been recorded in the ancient palm leaf chronicle Mahavamsa. The term 'Vedda' (or 'hunter') is a name given by Sinhala-speakers, while "Vaden" is the term used in Tamil. The people refer to themselves as Vanniyaletto or Vanniyalatto (forest or nature dwellers). Castaway Robert Knox published the first Western account in 1681 (An Historical Relation of the Island of Ceylon). In Germany as early as 1881 , a report was published on the Vedda by physical anthropologist Rudolph Virchow, translated into English as The Veddhas of Ceylon and their Relation to the Neighboring Tribes (Virchow 1886). The Veddas by C. G. and Brenda Z. Seligmann appeared in 1911.

In the past century a number of academic studies of the Vedda have been conducted (Parker 1909; Goonetilleke 1960; Wijesekera 1964; de Silva 1972; de Silva 1990; Dharmadasa and Sa- 
marasinghe 1990; Meegaskumbura 1993, 1995; Ramanayake 1995; Silva 2002; Blundell 2004, 2007, 2008, In Press). Studies have occurred especially in the Mahiyangana and Maha Oya areas (e.g., Seligmann and Seligmann 1911; Spittle 1941), Anuradhapura (e.g., Brow 1978), and the East Coast (e.g., Dart 1990).

Dart (1990:80) explains:

The Veddas have a long history of existence as a distinct group, and have maintained cultural traditions which are distinct from those of present-day Tamils and Sinhalese.

Vanniyaletto believe in the transmigration of human spirit that allows for ancestors known as na yakku to assist with matters of the living. Every person in the community is enabled to call on na yakku to request specific assistance (Dabana Gunawardhana 2003 pers. comm.; Puspahumara 2000; Obeyesekere 2002, n.d.).

Another feature of the Vedda communities is that they occupy a transition area "as a buffer" between the Sinhala and Tamil. According to James Brow (1978: 36), there is parallel sense of commonality among Sinhala-speaking Vedda and the Tamil-speaking Vedda, as one people connected across societies and regions. Today their populations range in a swath across from southeast of Anuradhapura to the east and south, including parts of the central mountains to the east coast and again south to Bibile. Yet in earlier times their extent covered the entire country where nature offered a bounty of resources.

Overall, Sri Lanka has been inhabited by Mesolithic societies for about 30,000 years with evidence discovered in Fa Hien Cave at Pahiyangala (Figure 3). It is probably the largest cave site of its kind in the land near Balangoda; first examined by P. E. P. Deraniyagala and Douglas Osborne in the 1960s. A 3.75 meter habitation deposit rich in charcoal provided evidence of a Mesolithic industry and habitation site with the remains of worked stones, dried food, shells, animal bones and people. The term Mesolithic has been used since the late 19 th century to define the transition period from hunting and gathering to food producing societies (Kennedy 1984). Also, such remains were found in prominent caves such as Kitulgala and Batadomba. I especially mention Fa Hien Cave for there is a historic connection. It was here at Pahiyangala that the famous Chinese Buddhist mendicant, known as Fa Hsien, sojourned at the cave in the 5th century CE during the reign of King Mahanama. Currently, a Buddhist shrine remains in the centre of the cave with a reclining Buddha statue and a side chamber dating from the Kandyan era of the 17 th-18th centuries.

Kennedy affirms that there is a biological-historic continuum connecting the Vedda with early occupation at Batadombalena (ca. 31,000-13,000 B.P.) and other sites where Mesolithic remains have been excavated, such as Belilena Kitulgala (ca. 30,000-9,000 B.P.), Bellanbandi Palassa (ca. 6,500 B.P.), and the Phiyangala caves. These are currently the earliest known anatomically modern humans from South Asia (Kennedy cited

Bulletin of the Indo-Pacific Prehistory Association 32 (2012): 23-28 ISSN: $1835-1794$ in Deraniyagala 2002). A skull found at Fa Hien Cave, Pahiyangala, has been dated to 37,000 B.P. making it the oldest Mesolithic finds in South Asia. Indications show that the region was exploited for fauna during this entire timespan in a similar way (Kennedy and Deraniyagala 1989).

I mention this since the continuum is important for understanding such a rich and ancient past in the context of the historic era. Etymologically the term vedda refers to a hunting group from the Sanskrit vyadha and has been applied to various peoples in Southern Asia, including Borneo and Sumatra. Among the Sinhala-speakers, this term Vedda is a reference to small scale forest-resource gatherers live in groups of about one to five families with four to ten members in a family (Deraniyagala 1992:387).

The Vedda have been compared to the Kadar and Chench of continental South Asia and in Southeast Asia with the Andaman Islanders and the Semang of the Malaysian Peninsula (Deraniyagala 1992: 395-429).

Groups known as the 'Naga' and 'Yakka' were noted at the arrival time of the 'Sinhalese' with Prince Vijaya in the 6th century B.C.E., yet became displaced in history. In the ancient chronicle Mahavamsa, the indigenous 'Yakka princess' Kuweni wed Prince Vijaya, the 'first recorded Sinhala king'. Thus, the Sri Lanka population claims partial hereditary descent from the Vedda, as their own heritage officially testifies in the $M a$ havamsa.

Later, the Chinese Buddhist pilgrim Hsuien Tsang in the 7th century C.E., noted 'forest dwellers' were referred to as Yakka living in the southeast of the country.

\section{KANDYAN LEGACY TO THE PRESENT}

Across the ages of ancient kingdoms from Anuradhapura to the Kanydan rulers, the Vedda were treated as highly appreciated and respected members of the royal court. They lived in the Uva Province, Central Province, and Eastern Province. Their responsibility to the royal state included the heraldry of the ritual perahera, honouring Buddhist shrines in procession, such as the Temple of the Tooth (Dalida Maligava) in Kandy, and supplying the 'essence of natural lands' such as honey to the nobility. According to Obeyesekere, the Vedda were treated as high nobility, considered brothers to hereditary 'Nayakkar kings'. (Gananath Obeyesekere is working on publishing the Kandyan period chronicle: väddi vamsaya). 


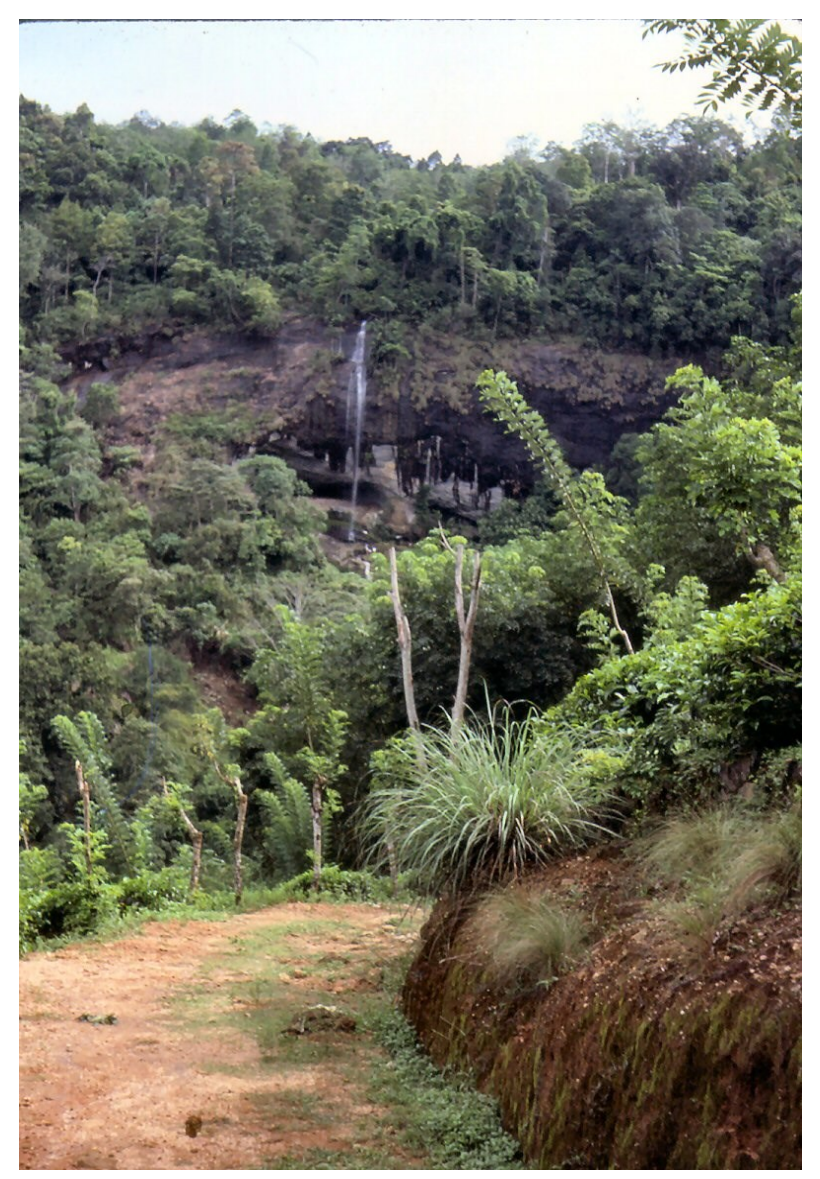

Figure 3. Fa Hien Cave at Pahiyangala (courtesy of Kenneth Kennedy).

In 1817-1818 the Vedda rallied with an upstart Sinhala insurrection led by Dorai Svami against the newly established British rule over the entire island, which had displaced the authority of the up-country Kandyan rulers. The rebellion crushed by the British military, eliminated the local aristocracy and Vedda influence. Following this, the Vedda groups declined throughout the 19 th century. By the turn of the 20th century, they were considered to be on the verge of extinction (Seligmann and Seligmann 1911), or soon to be absorbed into the dominant Sinhala/ Tamil populations (Deraniyagala 1963; Dharmadasa and Samarasinghe 1990). In the mid-20th century Mahaweli River irrigation projects gave farmlands for the Sinhala population for expansion into the Vedda's life support regions. Where irrigation systems have been renovated and made available since the 1950s, thousands of Vedda have opted to resettle and engage in paddy cultivation and along with Sinhala farmers acquired land in the Mahaweli River plains.

James Brow (1978) referred to Anuradhapura area Vedda as self-identified, admittedly Sinhala assimilated cultivators with approximately a population of seven thousand. In Dambana, Uruwargiye Vanniyala, successor and son of elder Tissahamy, estimated that there are 800 people holding to 'traditional' Vedda community values (pers. comm. 2003).

\section{APPRECIATION OF AN ETHNIC MINORITY}

More effort is required if Sri Lanka is to demonstrate its own historic and prehistoric past with cultural and political integrity, as well as the living values the Vedda continues to offer. The Vanniyaletto community is one of the most historically documented in South Asia, yet neglected as a knowledge-based ethnic group in the country's pluralistic society. In its complex and lengthy ethnohistory (Deraniyagala 1992:395-429), what values are retained in their way of life in eastern and central Sri Lanka that could be useful to know?

As the 'green revolution' of South Asia began in the 1960s, indigenous knowledge declined in Sri Lanka. Therefore, only in remote places could the old way of life be found. In Uva Province, Mahiyangana, Moneragala, and Badalkumbura districts have conducted a project "Documentation and Using Indigenous Knowledge" since 2000 to search out and record systems of local knowledge in order to promote them as something of sustainable worth and value to the current generation. The project combines (1.) agro-biodiversity for sustainable farming and (2.) traditional health practices. Field director K. A. Jayaratne Kahandawa, based in Badulla (Uva) has been assisting with non-governmental organizations (NGOs) working on development projects such as the Norwegian funded "Future in Our Hands," and South Asian Network on Food Ecology and Culture (SANFEC) to investigate the valuable utility of herbal medicines and knowledge of flora understood by the Vanniyaletto and other local rural communities. Quietly, these 'people of nature' are being appreciated as a valuable resource of local knowledge.

If the Vedda are the heirs of an existence dating back to the Mesolithic cultures of South Asia, they represents a sphere of expressions that requires global attention in conserving a folk diversity that is rapidly disappearing. Of course, the national mainstream population is curious and proud of such people living in their country. However, heritage stemming from a sense of 'indigenousness' is not proactive with the 'urbanite communities'. A living folk life cultural or performance centre is not matched with the equality of museums built as static institutions honouring the cultural inventory of ancient civilization.

\section{CONCLUSION}

The Vedda live in a syncretism of heritage beliefs and ways of doing things stemming from local origins that weave together a contemporary society (Obeyesekere 1982). Specific knowledge is found among the Vedda in terms of the forest and belief systems based on nature. This knowledge-sharing is a valuable asset as intangible cultural heritage that could assist neighbouring Sinhala and Tamil 
communities. Vanniyaletto intentionally live in small groups as they are reliant on limited natural resources. Throughout their history, they have remained essentially peaceful, without initiating violence against other local groups (Gunawardhana 1993).

A few curious tourists, both local and from abroad, make their way to the periphery of a national wildlife reserve to visit the village of the Vedda at Dambana, near Mahiyangana. To date, although the Vanniyaletto live in a land of significant ancient world heritage, they struggle to obtain substantial community centre dedicated to their existence (although in Mahiyangana there is a simple display building). The Vanniyaletto offer intangibles that are commonly ignored in a world of tangible monuments.

\section{ACKNOWLEDGEMENTS}

I am grateful to my colleagues in Taiwan, Sri Lanka, and USA for their support in preparing the initial IPPA Taipei Congress paper drafts. Thanks to Jeanette Zerneke and later Kitsch Liao who helped editing this final version. Originally I had planned to include the cultural resource management developments in Southeast Asia reflecting on the programs of the Regional Centre for Archaeology and Fine Arts Centre of the Southeast Asian Ministers of Education Organization (SEAMEO) hosted by the Government of Thailand (SPAFA). I acknowledge the orientation of given by Gananath Obeyesekere who has tirelessly championed the legacy of Vanniyaletto into the societal equation of valued heritage resources

(http://vedda.org/obeyesekere1.htm). Appreciation is given to Siran Deraniyagala, Douglas Osborne, and Kenneth Kennedy for their personal efforts to enhance my understanding from prehistory. K. A. J. Kahandawa in Badulla, introduced me to the work he is conducting on a valued living heritage on the verge of extinction, and how the acquisition of local knowledge could be useful to our modern society. Conrad Ranawake supported the project that included a field visit to the Dambana Vedda community. Dambana Gunawardhana, university graduate, of the community in Dambana, shared his valuable knowledge. Roland Silva, President of International Council on Monuments and Sites (ICOMOS) 1990-1999, and L. K. Karunaratne offered their guidance for understanding the utility and extent of cultural resource management in Sri Lanka for historic cultures.

\section{REFERENCES}

Blundell, David. 2004. Vedda (Vanniyaletto): A vital minority in Sri Lanka's historically plural society. Presented at Panel 6-8: Negotiating States and Ethnicity of 18th International Association of Historians of Asia (IAHA) Conference. Paradigm Shift in Asia: East, Southeast, South Asia, and the Pacific in Comparative Perspective. Academia Sinica, Taipei. December 6-10.

2007. Where have all the Vedda (Vanniyaletto) Gone? Sri Lanka cultural heritage revisited. Presented at the South Asian Studies Association (SASA) Conference. Asian Studies on the Pacific Coast. Loyola Marymount University. Los Angeles, CA. April 27-29.

.2008. Indigenous culture integrity: Vignettes in Taiwan and Sri Lanka. Proceedings of the World Summit of Indigenous Cultures. Banqiao, Taipei. April 13. Website: http://indigenous.pristine.net/events/2008/wsic/presentat ions/david_blundell_paper.html

Bulletin of the Indo-Pacific Prehistory Association 32 (2012): 23-28 ISSN: $1835-1794$
2011. Performance of Ruhunu mask dance at the 2010 Sri Lanka Design Festival: Comic relief and healing. Presented at the South Asian Studies Association (SASA) Conference, Virginia Commonwealth University, Richmond, VA. April 10-12.

In Press. Struggling identities: Vanniyaletto (Vedda) of Sri Lanka. Biological and Cultural Diversity of Man and the Development Consequence in Asia. Ranjana Ray and S. B. Chakrabarti (Indian Statistical Institute, Anthropological Survey of India) (eds.). Asiatic Society.

Brow, James. 1978. Veddha Villages of Anuradhapura: The Historical Anthropology of Community in Sri Lanka. Seattle: University of Washington Press.

Dart, Jon. 1990. The coast Veddas: Dimensions of marginality. In Dharmadasa and Samarasinghe (eds.). The Vanishing Aborigines, pp. 67-83. Colombo: ICES

Deraniyagala, P. E. P. 1963. The hybridization of the Veddas with the Sinhalese. Spolia Zelanica 30(1): 11-147.

Deraniyagala, S. U. 1992. The Prehistory of Sri Lanka: An Ecological Perspective. Memoir Volume 8, Part I-II. Colombo: Department of Archaeological Survey, Sri Lanka.

Deraniyagala, S. U. 2002. The prehistory and protohistory of Sri Lanka--A synthesis. The Prehistory of Sri Lanka: An Ecological Perspective. Chapter 7. Online: http://www.the-prehistory-of-sri-lanka.de

de Silva, C. R. 1990. The Vedda and his mentors: some theoretical and methodological considerations. In Dharmadasa and Samarasinghe (eds.). The Vanishing Aborigines, pp. 34-47. Colombo: ICES.

de Silva, M. W. Sugathapala. 1972. Vedda Language of Ceylon. Munchen: R. Kitzinger.

Dharmadasa, K. N. O., and S. W. R. de A. Samarasinghe, (eds.) 1990. The Vanishing Aborigines: Sri Lanka's Veddas in Transition. Colombo: International Centre for Ethnic Studies (ICES).

Goonetilleke, H. A. I. 1960. A bibliography of the Veddah. Ceylon. Journal of Sri Lanka Studies 3:96-106.

Gunawardhana, Dambane. 1993. The social organization of the traditional Vedda community. Soba 4(3):21-24.

Kennedy, K. A. R. 1984. Biological adaptations and affinities of Mesolithic South Asians. In J. R. Lukacs (ed.). The People of South Asia: The Biological Anthropology of India, Pakistan and Nepal, pp. 29-57. New York: Plenum Press.

Kennedy, K. A. R. and S. U. Deraniyagala. 1989. Fossil remains of 28,000-year-old hominids from Sri Lanka. Current Anthropology 30(3): 394-398.

Knox, Robert. 1911. [1681] An Historical Relation of the Island of Ceylon. Glasgow: James MacLehose and Sons.

Mahavamsa. 1950. [1912] version by Geiger-Bode. Colombo: Ceylon Government Information Department. 
Meegaskumbura, P. B. 1993. The rituals and Santhi Karma (invocations) of Vedda community. Soba 4(3): 36-40.

. 1995. Sirilaka Vedigana Puranaya. Colombo: Pinidiya Publications. (In Sinhala)

Obeyesekere, Gananath. 1982. The principles of religious syncretism and the Buddhist pantheon in Sri Lanka. In Fred W. Clothey (ed.). Images of Man: Religion and Historical Process in South Asia, pp. 15-33. Madras: New Era Publishers.

Obeyesekere, Gananath. 2002. Where have all the Väddas gone? Buddhism and aboriginality in Sri Lanka. In Neluka Silva (ed.). The Hybrid Island: Culture Crossing and the Invention of Identity in Sri Lanka, pp. 1-19. Colombo: Social Scientists' Association.

Obeyesekere, Gananath. n.d. Colonial Histories and Vädda Primitivism: An Unorthodox Reading of Kandy Period Texts. Online: http://vedda.org/obeyesekere1.htm

Parker, H. 1909. Ancient Ceylon. London: Luzac and Co.
Puspakumara, W. M. N. 2000. Rituals and Beliefs of Veddas. Unpublished MA thesis for Sinhala Special Degree. (In Sinhala)

Ramanayake, R. A. D. K. 1995. Bibliography on Veddahs. Delgoda: R. A. D. K. Ramanayake Publisher.

Seligmann, C. G., and Brenda Z. Seligmann. 1911. The Veddas. Cambridge: Cambridge University Press.

Silva, Neluka (ed.). 2002. The Hybrid Island: Culture Crossing and the Invention of Identity in Sri Lanka. Colombo: Social Scientists' Association.

Spittel, R. L. 1941. Vanishing Veddas. Loris 2(4): 195-201.

Virchow, Rudolph. 1886. The Veddhas of Ceylon and their relation to the neighboring tribes. The Journal of the Ceylon branch of the Royal Asiatic Society $9(3): 349-495$.

Wijesekera, N. D. 1964. Veddas in Transition. Colombo: Gunasena. 